Journal of Applied Pharmaceutical Science Vol. 5 (12), pp. 111-116, December, 2015

Available online at http://www.japsonline.com

DOI: $10.7324 / \mathrm{JAPS} .2015 .501219$

ISSN 2231-3354 (cc) BY-NC-sA

\title{
In-vitro antioxidative potential of methanolic aerial extracts from three ethnomedicinal plants of Assam: A Comparative Study
}

\author{
Kabita Mahato*, Bibhuti Bhusan Kakoti, Sudarshana Borah, Mritunjay Kumar \\ Department of Pharmaceutical Sciences, Dibrugarh University, Dibrugarh-786004, Assam, India.
}

\begin{tabular}{l} 
ARTICLE INFO \\
\hline Article history: \\
Received on: 05/07/2015 \\
Revised on: 15/08/2015 \\
Accepted on: 09/09/2015 \\
Available online: 27/12/2015 \\
\hline Key words: \\
Calamus leptospadix Griff., \\
Lasia spinosa Lour., \\
Heliotropium indicum Linn., \\
Antioxidative potential, \\
DPPH.
\end{tabular}

\begin{abstract}
Antioxidants are the substances that neutralize free radicals or their actions. The traditional antioxidant phytochemicals from plants have been reported to inhibit the propagation of free radical reactions and to protect the human body from disease. The use of synthetic antioxidants has always been questioned because of their toxicity therefore researches are being carried out on plants nowadays to bring out the potent natural antioxidants. With this intent three ethnomedicinal plants of Assam viz., Calamus leptospadix Griff., Heliotropium indicum Linn., Lasia spinosa Lour. were explored with a view to evaluate their in-vitro antioxidative potentials. The methanolic aerial extracts were studied for phytochemical analysis and antioxidative properties by different invitro assays: DPPH radical scavenging method, Nitric oxide radical scavenging activity, Hydrogen peroxide radical scavenging activity, Total phenolic content and Total flavonoid content. The percentage of inhibition was calculated by comparing the absorbance values of the control and test samples. The study conducted revealed that methanolic extract of Calamus leptospadix (CL) exhibited the highest DPPH radical scavenging activity (IC50 value of $29 \pm 3.24 \mu \mathrm{g} / \mathrm{ml})$, Nitric oxide radical scavenging activity $(233.33 \pm 3.54 \mu \mathrm{g} / \mathrm{ml})$, Total phenolic content $(8.02 \pm 0.32 \mu \mathrm{g} / \mathrm{ml}$ expressed as gallic acid equivalents) and Total flavonoid contents $(61.71 \pm 1.16 \mu \mathrm{g} / \mathrm{ml}$ expressed as quercetin equivalents). Methanolic extract of Lasia spinosa (LS) showed highest hydrogen peroxide radical scavenging activity (IC50 value of $221.89 \pm 2.14 \mu \mathrm{g} / \mathrm{ml}$ ). The results obtained in the present study indicate that aerial parts of Calamus leptospadix have potent, Lasia spinosa have moderate and Heliotropium indicum (HI) have mild antioxidant and free radical scavenging activity.
\end{abstract}

\section{INTRODUCTION}

Since prehistoric times, the medicinal properties of plants have been investigated in the contemporary scientific developments throughout the world, due to their potent antioxidant activities. Antioxidants are the substances that neutralize free radicals or their actions (Sies, 1996). There are two major classes of antioxidants viz., enzymatic and nonenzymatic. The enzymatic antioxidants that are produced endogenously include superoxide dismutase, catalase and glutathione peroxidase. The non-enzymatic antioxidants include tocopherols, carotenoids, ascorbic acid, flavonoids and tannins which are obtained naturally. As antioxidants prevent oxidative damage caused by free radicals, it can interfere with the oxidation process by reacting with free radicals, chelating catalytic metals and also by acting as oxygen scavengers

\footnotetext{
* Corresponding Author

Email: mahato6@gmail.com
}

(Buyukokuroglu et al, 2001). There is an increased corroboration for the participation of free radicals in the etiology of cancer, diabetes, cardiovascular diseases, autoimmune disorders, neurodegenerative diseases, aging etc (Beckman et al, 1998). A free radical is a compound with one or more unpaired electrons in its outer orbital (Jesberger et al, 1991).

Such unpaired electrons make these species unstable and reactive with other molecules due to the presence of unpaired electrons so they try to pair their electrons and generate a more stable compound (Karlsson, 1997). It is a highly reactive molecule or molecular fragment that contains one or more unpaired electrons in its outer orbit and is capable of independent existence (PhamHuy et al, 2008). Reactive Oxygen Species (ROS) are the most dangerous free radicals which are continuously generated inside the human body. These generated ROS are detoxified by the antioxidants present in the body although over production of ROS and inadequate antioxidant defense can easily affect and persuade oxidative damage to proteins, lipids, lipoproteins and DNA (Farber, 1994). ROS formed in vivo, such as superoxide anion, 
hydroxyl radical and hydrogen peroxide, are highly reactive and potentially damage transient chemical species. Tissue damage results from an imbalance between ROS-generating and scavenging systems that has been incriminated in the pathogenesis of a variety of disorders such as Alzheimer's disease, cancer, atherosclerosis, diabetes mellitus, hypertension, AIDS and aging ( Halliwell et al,1996, Mantle et al, 2000). In recent years, researches have been carried out to find natural antioxidants from plant materials. The natural antioxidants viz., flavonoids and other polyphenols have been reported to inhibit the propagation of free radical reactions, to protect the human body from disease and to retard lipid oxidative rancidity (Kinsella et al, 1993, Terao et al, 1997, Duthie, 1993).

In addition, the use of synthetic antioxidants has always been questioned because of their toxicity (Valentao et al, 2002). Therefore, numerous researches are being conducted on these bio-resources to seek for potent natural and effective antioxidants to restore the synthetic ones (Nusaiba et al, 2013).

With this intent, a comparative study on the in-vitro antioxidant activity of the methanolic aerial extracts from three ethnomedicinal plants of Assam were explored with a view to evaluate their antioxidative potentials which include the following assay methods: DPPH radical scavenging activity, Nitric oxide radical scavenging activity, Hydrogen peroxide Radical scavenging activity, Total phenolic content, Total flavonoid content. The selected plants are Calamus leptospadix Griff, Heliotropium indicum Linn, Lasia spinosa Lour.

\section{MATERIALS AND METHODS}

\section{Collection of plant materials}

The three medicinal plants were collected from different localities at different seasons based on their availability. The aerial parts of Calamus leptospadix Griff. (Family: Arecaceae) were collected from Jokai, Dibrugarh, Assam, India during the month of July, 2012; Heliotropium indicum Linn. (Family: Boraginaceae) and Lasia spinosa Lour (Family: Araceae) were collected from Dibrugarh University campus, Assam, India during the month of April, 2012 and September, 2012 respectively.

The plants were identified and authenticated by Dr. N. Odyuo, Botanical Survey of India, Eastern Regional Centre, Shillong. A voucher specimen of each plant (Specimen no. of Calamus leptospadix: Du/SB/2012/06, Reference no. BSI/ERC/2013/Tech/Plant identification/636; Specimen no. of Heliotropium indicum: $\mathrm{Du} / \mathrm{KM} / 2012 / 07$, Reference no. BSI/ERC/2013/Tech/Plant identification/636; Specimen no. of Lasia spinosa: Du/MTJ/2012/07, Reference no. BSI/ERC/2013/Tech/Plant identification/638) has been kept in Department of Pharmaceutical Sciences, Dibrugarh University, Assam for future references.

The aerial parts of the plants were washed thoroughly with water and then dried partially under sunlight and partially under shade and stored inside air tight container for further study.

\section{Preparation of methanolic extracts}

The aerial portion of the plants were cut up, cleaned assiduously and then dried partially under sunlight and partially under shade. The dried pieces were then pulverized in a mechanical grinder to coarse powder. $250 \mathrm{~g}$ of powdered crude drugs were extracted by soxhelation (Continuous hot extraction) with $1000 \mathrm{ml}$ of methanol for 18 hours at $65^{\circ} \mathrm{C}$ after pretreatment with $1000 \mathrm{ml}$ of petroleum ether $\left(40-60^{\circ}\right)$ in order to defat the material.

When the powdered material had become totally exhausted on treatment with methanol, the solvent from the extract was recovered with rotary evaporator. The concentrated extracts were dried and stored in a desiccator for use in subsequent experiments.

\section{Chemicals and Equipments}

Chemicals that were needed include 1,1- Diphenyl -2 picryl hydrazyl (DPPH), Gallic acid and Aluminium chloride acquired from Sigma-Aldrich Chemical Co., Otto Chemie Pvt. Ltd. and Rankem Chemical Co., (India). Rest of the chemicals Ascorbic acid, Sodium nitroprusside, Curcumin, Sulphanilic acid, Glacial acetic acid, Naphthyl ethylene diamine dihydrochloride, O-Phosphoric acid, Hydrogen peroxide, Folin- Ciocalteu reagent, Sodium carbonate, Potassium acetate were purchased from Himedia Laboratories and Loba Chemie Pvt. Ltd., (Mumbai, India).

Equipments required for the measurement of absorbance spectrophotometrically and incubation were UV Spectrophotometer (Specord $® 50$ Plus, Analytikjena) and biological incubator.

\section{Preliminary phytochemical analysis}

Preliminary phytochemical analyses of the three different methanolic extracts were carried out to be cognizant of the different phytoconstituents present in the extracts. The different phytoconstituents of the methanolic extracts of Calamus leptospadix (MECL), Heliotropium indicum (MEHI), Lasia spinosa (MELS) have been shown in the table 1.

\section{Determination of in-vitro antioxidative potential DPPH radical scavenging activity}

Standard ascorbic acid solution $(1 \mathrm{mg} / \mathrm{ml})$ and test sample solutions $(1 \mathrm{mg} / \mathrm{ml})$ of each different aerial extracts were prepared at concentrations of $20,40,60,80$ and $100 \mu \mathrm{g} / \mathrm{ml}$. $1 \mathrm{ml}$ of $0.3 \mathrm{mM}$ DPPH solution was added to $2 \mathrm{ml}$ of each different concentrations of standard and test solutions and incubated at dark for 30 minutes at room temperature after it was vigorously shaken. $1 \mathrm{ml}$ of $0.3 \mathrm{mM}$ DPPH solution was added to $2 \mathrm{ml}$ of methanol and this solution was taken as control which was allowed to incubate at dark for $30 \mathrm{mins}$ at room temperature. After $30 \mathrm{~min}$, absorbance was measured at $517 \mathrm{~nm}$ taking methanol as blank using UV-Visible spectrophotometer. The percentage of inhibition was calculated by comparing the absorbance values of the control and test samples. All the tests were performed in triplicate. The capability to 
scavenge the DPPH radical was calculated as the inhibition percentage of free radical by the sample and standard by using the following formula:

$$
\% \text { Inhibition of DPPH radicals }=\frac{\mathrm{A} \mathrm{o}-\mathrm{At}}{\mathrm{Ao}} \times 100
$$

Where $A_{O \text { Control }}$ is the absorbance of the control reaction and $A_{t}$ is the absorbance of test/standard. The antioxidant activity of the extract was expressed as $\mathrm{IC}_{50}$. The $\mathrm{IC}_{50}$ value is defined as the concentration $(\mu \mathrm{g} / \mathrm{mL})$ of extract that inhibits the formation of DPPH radicals by $50 \%$ (Prasad et al, 2009).

\section{Nitric oxide (NO) radical scavenging activity}

Standard curcumin $(1 \mathrm{mg} / \mathrm{ml})$ and test sample solutions $(1 \mathrm{mg} / \mathrm{ml})$ of each different aerial extracts were prepared at concentrations of $80,160,320,500,800$ and $1000 \mu \mathrm{g} / \mathrm{ml}$. To $1 \mathrm{ml}$ of standard and each different methanolic extract solutions $1 \mathrm{ml}$ of sodium nitroprusside and $1 \mathrm{ml}$ of phosphate buffer saline $\mathrm{pH} 7.4$ were added and incubated at $25^{\circ} \mathrm{C}$ for $150 \mathrm{~min}$. After incubation, $1 \mathrm{ml}$ of the above mixture was taken and $1 \mathrm{ml}$ of Griess reagent was added to it and then allowed to stand in dark for 30mins and then absorbance was taken at $546 \mathrm{~nm}$. $1 \mathrm{ml}$ of distilled water, $1 \mathrm{ml}$ of sodium nitroprusside and $1 \mathrm{ml}$ of phosphate buffer were mixed, incubated at $25{ }^{\circ} \mathrm{C}$ for $150 \mathrm{~min}$. After incubation $1 \mathrm{ml}$ of Griess reagent was added to it and then allowed to stand in dark for 30 mins and then absorbance was taken at 546nm. This was taken as the control. The absorbance was measured spectrophotometrically in triplicates and radical-scavenging activity was expressed as the inhibition percentage of free radical by the sample/ standard and was calculated using the following formula:

$\%$ Inhibition of nitric oxide radicals $=\frac{\mathrm{Ao}-\mathrm{At}}{\mathrm{Ao}} \times 100$

Where, $\mathrm{A}_{0}$ is the absorbance of the control \& $\mathrm{A}_{\mathrm{t}}$ is the absorbance of test/ standard. Antioxidant activity of extract is expressed as $\mathrm{IC}_{50}$ value. The $\mathrm{IC}_{50}$ value is defined as the concentration $(\mu \mathrm{g} /$ $\mathrm{mL}$ ) of dry extract that inhibits the formation of nitric oxide by 50\% (Garrat, 1964).

\section{Hydrogen peroxide radical $\left(\mathrm{H}_{2} \mathrm{O}_{2}\right)$ scavenging activity}

Standard ascorbic acid $(1 \mathrm{mg} / \mathrm{ml})$ and test sample solutions $(1 \mathrm{mg} / \mathrm{ml})$ of each different aerial extracts were prepared at concentrations of 50, 100, 200, 400,600, 800 and $1000 \mu \mathrm{g} / \mathrm{ml}$. To $1 \mathrm{ml}$ of standard and each different methanolic extract solutions $0.6 \mathrm{ml}$ of $\mathrm{H}_{2} \mathrm{O}_{2}$ was added. Absorbance of $\mathrm{H}_{2} \mathrm{O}_{2}$ at $230 \mathrm{~nm}$ was determined after 10 min against a blank solution containing the phosphate buffer without $\mathrm{H}_{2} \mathrm{O}_{2} .1 \mathrm{ml}$ of Phosphate buffer and $0.6 \mathrm{ml}$ of $\mathrm{H}_{2} \mathrm{O}_{2}$ was used as control. Reactions were carried out in triplicate spectrophotometrically. The percentage of $\mathrm{H}_{2} \mathrm{O}_{2}$ scavenging of both the extracts and standard compounds were calculated. The percentage inhibition was calculated as:

$$
\% \text { Inhibition of } \mathrm{H}_{2} \mathrm{O}_{2} \text { radicals }=\frac{\mathrm{A} \mathrm{o}-\mathrm{At}}{\mathrm{Ao}} \times 100
$$

Where $A_{0}$ Control is the absorbance of the control reaction and $A_{t}$ test is the absorbance in the presence of the sample of the extracts The antioxidant activity of the extract is expressed as $\mathrm{IC}_{50}$. The
$\mathrm{IC}_{50}$ value is defined as the concentration $(\mu \mathrm{g} / \mathrm{ml})$ of dry extract that inhibits the formation of $\mathrm{H}_{2} \mathrm{O}_{2}$ radicals by $50 \%$ (Ruch et al, 1989).

\section{Total phenolic content}

Standard gallic acid $(1 \mathrm{mg} / \mathrm{ml})$ and test sample solutions $(1 \mathrm{mg} / \mathrm{ml})$ of each different aerial extracts were prepared at concentrations of $20,40,60,80,100 \mu \mathrm{g} / \mathrm{ml}$. $1 \mathrm{ml}$ of standard and each different methanolic extract solutions was mixed with $5 \mathrm{ml}$ of folin-ciocalteu reagent (diluted 10 fold) and $4 \mathrm{ml}$ of sodium carbonate. Absorbance was measured spectrophotometrically in triplicates at $765 \mathrm{~nm}$. $1 \mathrm{ml}$ of distilled water mixed with $5 \mathrm{ml}$ of folin-ciocalteu reagent and $4 \mathrm{ml}$ of sodium carbonate was taken as control. All determination was performed in triplicate. The total phenolic compound in the extract expressed in Gallic acid equivalents (GAE) was calculated by the following formula (Mcdonald et al, 2001):

$$
T=\mathrm{C} \times \frac{\mathrm{V}}{M}
$$

Where, $\mathrm{T}=$ Total phenolic contents, $\mathrm{mg} \mathrm{g}^{-1}$ plant extract, in Gallic Acid Equivalent (GAE),

$\mathrm{C}=$ Concentration $\left(\mathrm{mg} \mathrm{mL} \mathrm{m}^{-1}\right)$ of Gallic acid obtained from calibration curve,

$\mathrm{V}=$ Volume of extract $(\mathrm{mL})$,

$\mathrm{M}=$ Weight $(\mathrm{g})$ of methanolic plant extract.

\section{Total flavonoid content}

Total soluble flavonoid content of the extracts was determined with aluminium nitrate using quercetin as the standard (Hsu, 2006). $1 \mathrm{mg}$ of each different extract was added to $1 \mathrm{~mL}$ of $80 \%$ ethanol. An aliquot of $0.5 \mathrm{~mL}$ was added to test tubes containing $0.1 \mathrm{~mL}$ of $10 \%$ aluminium nitrate, $0.1 \mathrm{~mL}$ of $1 \mathrm{M}$ potassium acetate and $4.3 \mathrm{~mL}$ of $80 \%$ ethanol. The absorbance of the supernatant was measured at $415 \mathrm{~nm}$ after incubation at room temperature for $40 \mathrm{~min}$. The total flavonoid content in the extracts was determined as $\mu \mathrm{g}$ quercetin equivalent by using the standard quercetin graph and using the following formula (Ebrahimzadeh et al, 2008)

$$
T=\mathrm{C} \times \frac{\mathrm{V}}{M}
$$

Where, $\mathrm{T}=$ Total flavonoid content, $\mathrm{mg}^{-1}$ plant extract, in Quercetin Equivalent (QE),

$\mathrm{C}=$ Concentration $\left(\mathrm{mg} \mathrm{mL}^{-1}\right)$ of Quercetin obtained from calibration curve,

$\mathrm{V}=$ Volume of extract $(\mathrm{mL})$,

$\mathrm{M}=$ Weight (mg) of methanolic plant extract.

\section{Statistical Analysis}

The experimental readings were expressed as Mean \pm SEM of six replicates of each antioxidant procedure and hence $\mathrm{IC}_{50}$ value was calculated out. Comparisons have been made of the three different methanolic plant extracts. $\mathrm{P}<0.05$ was considered significant, $\mathrm{P}<0.01$ was considered more significant and $\mathrm{P}>0.05$ was considered non-significant. 


\section{RESULTS AND DISCUSSION}

\section{Phytochemical analysis}

Amongst the three medicinal plants, MECL showed the highest phytoconstituents, followed by MEHI and MELS as shown in Table: 1 .

Table1: Preliminary phytochemical analysis of methanolic plant extracts

\begin{tabular}{lccc}
\hline Phytochemical tests & MECL & MEHI & MELS \\
\hline Alkaloids & + & + & + \\
Flavonoids & + & + & - \\
Glycosides & + & - & - \\
Carbohydrates & + & - & - \\
Lignin & + & - & - \\
Steroids & + & + & - \\
Saponins & + & + & + \\
Fats \&Oils & + & - & - \\
Amino acids & - & + & + \\
Proteins & - & + & - \\
Gums & - & - & + \\
Tannins \& Phenols & + & + & \\
\hline + denotes positive result. & & \\
- denotes negative result. & \\
MECL= Methanolic extract of Calamus leptospadix. & \\
MEHI =Methanolic extract of Heliotropium indicum. & \\
MELS= Methanolic extract of Lasia spinosa. &
\end{tabular}

\section{In-vitro antioxidative potential} Inhibition of DPPH radicals

DPPH is a stable free radical at room temperature and accepts electron or hydrogen radical to develop into a stable diamagnetic molecule (Yesilyurt et al, 2008). The reduction capability of DPPH was determined by the decrease in its absorbance at $517 \mathrm{~nm}$, which is induced by antioxidants. Iron is capable of generating free radicals from peroxides by Fenton reactions, and minimization of the $\mathrm{Fe}^{2}+$ concentration in the Fenton reaction affords protection against oxidative damage.

Table 2: DPPH radical scavenging activity.

\begin{tabular}{lll}
\hline $\begin{array}{c}\text { Serial } \\
\text { no. }\end{array}$ & \multicolumn{1}{c}{$\begin{array}{c}\text { Standard and different aerial plant } \\
\text { extracts }\end{array}$} & \multicolumn{1}{c}{ IC50 Values } \\
\hline 1. & Ascorbic acid & $17.37 \pm 1.05 \mu \mathrm{g} / \mathrm{ml}$ \\
2. & Calamus leptospadix & $29 \pm 3.24 \mu \mathrm{g} / \mathrm{ml}$ \\
3. & Lasia spinosa & $38.48 \pm 3.78 \mu \mathrm{g} / \mathrm{ml}$ \\
4. & Heliotropium indicum & $120.81 \pm 4.73 \mu \mathrm{g} / \mathrm{ml}$ \\
\hline
\end{tabular}

\section{DPPH Scavenging Activity}

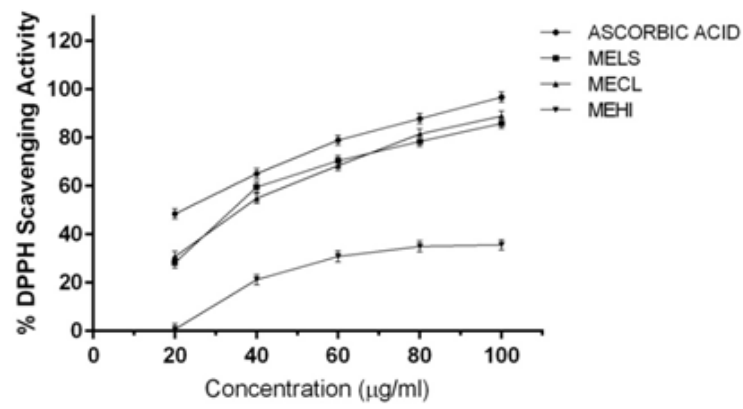

Fig 1: \% DPPH Scavenging Activity of MECL, MELS, MEHI compared with standard ascorbic acid. Data are expressed as Mean \pm SEM, $\mathrm{n}=$ 6. Statistical significance: $\mathrm{P}<0.01=$ MELS and MEHI compared to ascorbic acid $\mathrm{P}<0.05=$ MECL compared to ascorbic acid
The addition of different plant extracts interferes with the ferrous ferrozine complex and the formation of the red colored complex decreases with the increasing concentration. Table 2 shows the $\mathrm{IC}_{50}$ values of the plants extracts and standard. As per the $\mathrm{IC}_{50}$ values the antioxidant activity of the aerial plant extracts were as follows: Ascorbic acid $(17.37 \pm 1.05 \mu \mathrm{g} / \mathrm{ml})>$ Calamus leptospadix $(29 \pm 3.24 \mu \mathrm{g} / \mathrm{ml})>$ Lasia spinosa $(38.48 \pm 3.78$ $\mu \mathrm{g} / \mathrm{ml})>$ Heliotropium indicum $(120.81 \pm 4.73 \mu \mathrm{g} / \mathrm{ml})$.

\section{Inhibition of Nitric oxide (NO) radicals}

In vitro inhibition of nitric oxide radical is a measure of antioxidant activity of plant drugs. Nitric oxide plays an important role in various inflammatory processes but the overproduction of nitric oxide contributes to various diseases. The toxicity of NO increases greatly when it reacts with superoxide radical, forming the highly reactive peroxynitrite anion (Huie et al, 1993). The different plant extracts compete with oxygen to react with NO thereby inhibiting the formation of nitrite. $\mathrm{IC}_{50}$ values of the extracts compared with standard curcumin exhibiting nitric oxide scavenging activity has been shown at Table 3 . As per the $\mathrm{IC}_{50}$ values the antioxidant activity of the aerial plant extracts were as follows: Curcumin $(89.03 \pm 2.13 \mu \mathrm{g} / \mathrm{ml})>$ Calamus leptospadix $(233.33 \pm 3.54 \mu \mathrm{g} / \mathrm{ml})>$ Lasia spinosa $(313.46 \pm 3.79 \mu \mathrm{g} / \mathrm{ml})>$ Heliotropium indicum $(517.04 \pm 4.15 \mu \mathrm{g} / \mathrm{ml})$.

Table 3: Nitric oxide radical scavenging activity.

\begin{tabular}{lll}
\hline $\begin{array}{c}\text { Serial } \\
\text { no. }\end{array}$ & \multicolumn{1}{c}{$\begin{array}{c}\text { Standard and different aerial plant } \\
\text { extracts }\end{array}$} & \multicolumn{1}{c}{ IC50 Values } \\
\hline 1. & Curcumin & $89.03 \pm 2.13 \mu \mathrm{g} / \mathrm{ml}$ \\
2. & Calamus leptospadix & $233.33 \pm 3.54 \mu \mathrm{g} / \mathrm{ml}$ \\
3. & Lasia spinosa & $313.46 \pm 3.79 \mu \mathrm{g} / \mathrm{ml}$ \\
4. & Heliotropium indicum & $517.04 \pm 4.15 \mu \mathrm{g} / \mathrm{ml}$ \\
\hline
\end{tabular}

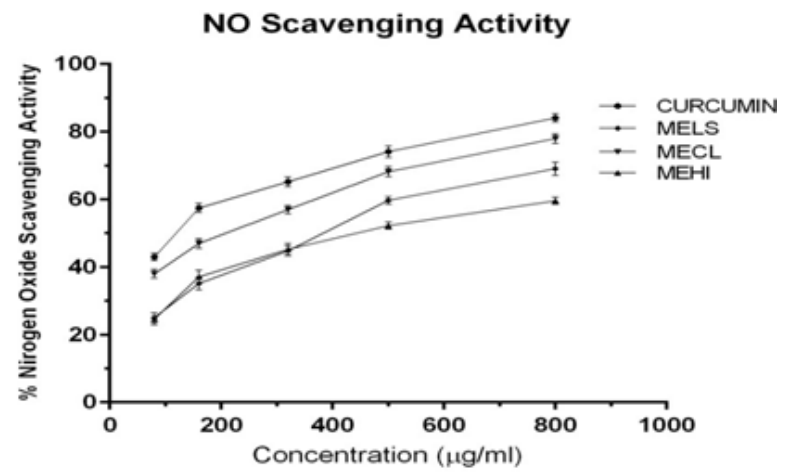

Fig. 2: NO Scavenging Activity of MECL, MELS, MEHI compared with standard curcumin. Data are expressed as Mean \pm SEM, $n=6$. Statistical significance: $\mathrm{P}<0.01=$ MELS and MEHI compared to curcumin; $\mathrm{P}<0.05=$ MECL compared to curcumin.

Inhibition of $\mathrm{Hydrogen}$ peroxide $\left(\mathrm{H}_{2} \mathrm{O}_{2}\right)$ radicals

Hydrogen peroxide itself is not only very reactive, but it can sometimes be toxic to cell as it provides hydroxyl radical in the cells. Thus removing $\mathrm{H}_{2} \mathrm{O}_{2}$ as well as $\mathrm{O}_{2}{ }^{-}$is very important for protection of food systems (Halliwell and Gutteridge, 1999). Table 4 shows the IC50 results of hydrogen peroxide radical scavenging activity. As per the $\mathrm{IC}_{50}$ values the antioxidant activity of the aerial plant extracts were as follows: Ascorbic acid (170.135 \pm 1.17 
$\mu \mathrm{g} / \mathrm{ml})>$ Lasia spinosa $(221.86 \pm 2.14 \mu \mathrm{g} / \mathrm{ml})>$ Calamus leptospadix $(276.87 \pm 2.86 \mu \mathrm{g} / \mathrm{ml})>$ Heliotropium indicum $(456.86$ $\pm 3.14 \mu \mathrm{g} / \mathrm{ml})$.

Table 3: Hydrogen peroxide radical scavenging activity.

\begin{tabular}{clc}
$\begin{array}{c}\text { Serial } \\
\text { no. }\end{array}$ & \multicolumn{1}{c}{$\begin{array}{c}\text { Standard and different aerial } \\
\text { plant extracts }\end{array}$} & $\begin{array}{c}\text { IC50 Values (Mean } \pm \\
\text { SEM) }\end{array}$ \\
\hline 1. & Ascorbic acid & $170.35 \pm 1.17 \mu \mathrm{g} / \mathrm{ml}$ \\
2. & Calamus leptospadix & $276.87 \pm 2.86 \mu \mathrm{g} / \mathrm{ml}$ \\
3. & Lasia spinosa & $221.86 \pm 2.14 \mu \mathrm{g} / \mathrm{ml}$ \\
4. & Heliotropium indicum & $456.86 \pm 3.14 \mu \mathrm{g} / \mathrm{ml}$ \\
\hline
\end{tabular}

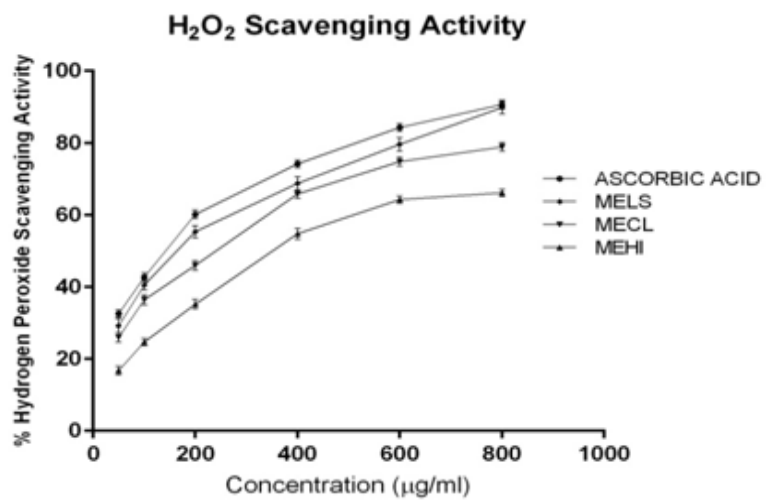

Fig. 3: $\mathrm{H}_{2} \mathrm{O}_{2}$ Scavenging Activity of MECL, MELS, MEHI compared with standard ascorbic acid. Data are expressed as Mean \pm SEM, $n=6$. Statistical significance: $\mathrm{P}<0.01=$ MECL and MEHI compared to ascorbic acid; $\mathrm{P}>0.05$ $=$ MELS c-ompared to ascorbic acid.

\section{Estimation of Total Phenolic Content}

The antioxidant activity of phenolics is mainly due to their redox properties, which plays an important role in adsorbing and neutralizing free radicals, quenching singlet and triplet oxygen or decomposing peroxides (Shah et al, 2010). For the estimation of total phenolic content present in the plant extract, Folin-Ciocalteu reagent was used. The standard curve equation of gallic acid was found to be: $y=0.017 x+0.000$ with $R^{2}=0.99$. The total phenolic content of methanolic extracts exhibited the following order: Calamus leptospadix $(8.02 \pm 0.32 \mu \mathrm{g} / \mathrm{ml})>$ Heliotropium indicum $(2.70 \pm 0.57 \mu \mathrm{g} / \mathrm{ml})>$ Lasia spinosa $(1.01 \pm 0.12 \mu \mathrm{g} / \mathrm{ml})$.

\section{Standard curve of Gallic Acid}

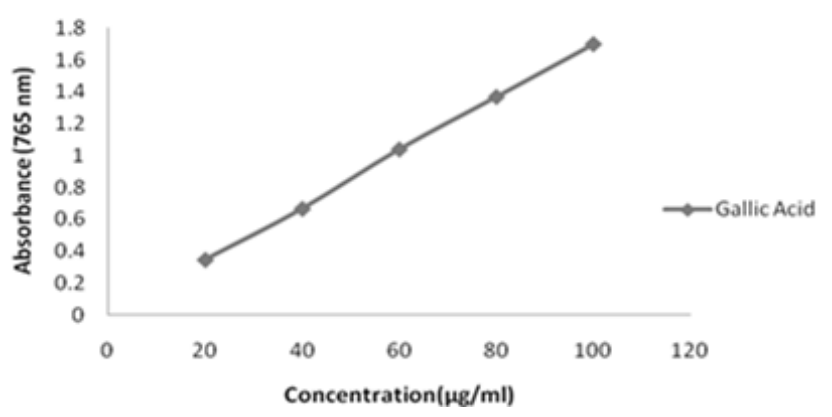

Fig. 4: Standard curve of Gallic Acid

\section{Estimation of total flavonoid content}

Flavonoids comprise the most widespread and diverse group of polyphenolic plant secondary metabolites. These compounds play an important role in antibacterial, antiviral, and anti-inflammatory, anti allergic, antithrombotic, vasodilatory actions. Besides it also exhibits free radical scavenging properties by either through scavenging or chelating process (Usmani, 2013, Ebrahimzadeh et al, 2008, Roy et al, 2013). Flavonoids are large class of benzo-pyrone derivatives, ubiquitous in plants exhibit antioxidant activity (Naskar et al, 2010). Total flavonoid content is expressed as $\mu \mathrm{g}$ of quercetin equivalents $(\mathrm{QE}) / \mathrm{mg}$ of extract. The standard curve equation of Quercetin was found to be: $y=0.008 x$ +0.032 with $\mathrm{R}^{2}=0.99$. The total phenolic content of methanolic extracts exhibited the following order: Calamus leptospadix (61.17 $\pm 1.16 \mu \mathrm{g} / \mathrm{ml})>$ Heliotropium indicum $(53.37 \pm 1.09 \mu \mathrm{g} / \mathrm{ml})>$ Lasia spinosa $(33.62 \pm 1.10 \mu \mathrm{g} / \mathrm{ml})$ per gram equivalents of quercetin.

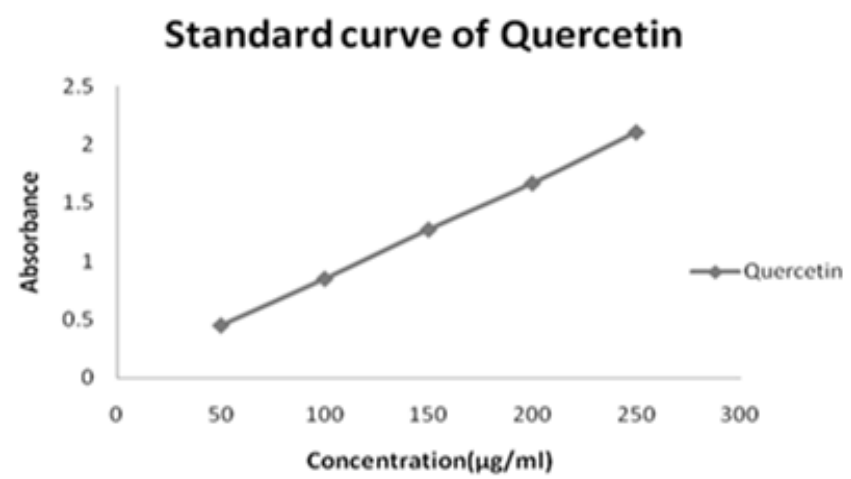

Fig. 5: Standard curve of Quercetin.

\section{CONCLUSION}

The investigation of the in-vitro antioxidant assays administered specifies that aerial parts of Calamus leptospadix have potent, Lasia spinosa have moderate and Heliotropium indicum have mild antioxidant activity which attributes to their radical scavenging mechanism. Calamus leptospadix showed better $\mathrm{H}_{2} \mathrm{O}_{2}$ scavenging activity than Lasia spinosa and Heliotropium indicum while Lasia spinosa showed better DPPH and NO scavenging activity than Calamus leptospadix and Heliotropium indicum. The lesser the $\mathrm{IC}_{50}$ value the better is the antioxidant activity and it was seen that amongst the three ethnomedicinal plants used for study Calamus leptospadix showed the least $\mathrm{IC}_{50}$ value. It can also be concluded that the antioxidant activity varied due to the difference in their phytochemical constituents. Further study can be done to isolate the phytochemical constituents from the plant having highest antioxidant activity.

\section{ACKNOWLEDGEMENT}

The Authors are thankful to Department of Pharmaceutical Sciences, Dibrugarh University, India for providing the research facilities for this work, supported by AICTE(All India Council Of Technical Education), Research Promotion Scheme (RPS) 2011, Grant No: 8023/RIB/RPS10/(NER)/2011-12. 


\section{REFERENCES}

Beckman K. B and Ames B. N. The free radical theory of aging matures. Physiological Reviews, 1998; 78 (2): 547-81.

Buyukokuroglu ME, Gulcin I, Oktay M, \& Kufrevioglu OI. Invitro antioxidant properties of dentrolene sodium. Pharmacological Research, 2001; 44: 491-494.

Duthie G.G. Lipid peroxidation. European Journal of Clinical Nutrition, 1993; 47(11): 759-764.

Ebrahimzadeh M.A., Pourmorad F., Bekhradnia A.R. Iron chelating activity screening, phenol and flavonoid content of some medicinal plants from Iran. African Journal of Biotechnology, 2008; 32: 43-49.

Ebrahimzadeh Mohammad Ali, Pourmorad Fereshteh, Bekhradnia Ahmad Reza. Iron chelating activity, phenol and flavonoid content of some medicinal plants from Iran. Afr. J. Biotechnology, 2008; 7: 3188-3192.

Farber JL. Mechanism of cell injury by activated oxygen. Environmental health perspective, 1994, 102: 17-24.

Garrat D.C. 1964. The quantitative analysis of drug. Chapman and Hall, Japan. 450-458.

Halliwell B., Gutteridge J.M.C. 1999. Free Radicals in Biology and Medicine. Oxford University Press, Oxford.

Huie RE and Padmaja S. The reaction of NO with superoxide.

Free Radical Res. Commun, 1993, 18: 195-199

Jesberger J.A., Richardson J.S. Oxygen free radicals in brain dysfunction. International Neuroscience, 1991; 57, 1-17.

Karlsson J. 1997. Introduction to Nutraology and Radical Formation. In: Antioxidants and Exercise. 1-143.

Kinsella J. E., Frankel E., German, B., Kanner J. Possible mechanisms for the protective role of antioxidants in wine and plant foods. Food Technology, 1993; 47: 85-89.

Mantle D., Eddeb F., Pickering A.T. Comparison of relative antioxidant activities of British medicinal plant species in vitro. Journal of Ethnopharmacology, 2000; 72: 47-51.

Mcdonald S., Prenzler P.D., Autolovich M., Robards K. Phenolic content and antioxidant activity of olive oil extracts. Food Chem., 2001; 73:73-84.

Naskar S., Islam A., Mazumder U. K., Saha P., Haldar P. K., and Gupta M., In Vitro and In Vivo Antioxidant Potential of Hydromethanolic Extract of Phoenix dactylifera Fruits, J. Sci. Res., 2010; 2 (1): 144-157.

Nusaiba S.A.W and Kumaraswamy Murugan. In vitro analysis on bactericidal screening and antioxidant potentiality of leaf and root extracts of Thottea siliquosa (Lam.) Ding Hou. An ethnobotanical plant, Asian Pac J Trop Biomed, 2013; 3(11): 859-865.
Pham-Huy LA, He H, Pham-Huy C. Free radicals: antioxidants in disease and health; Int. Journal Biomed. Sci.; 2008; 4: 89-96.

Prasad K.N., Yang B., Dong X., Jiang G., Zhang H., Xie H., Jiang Y. Flavonoid content, and antioxidant activities from Cinnamomum species. Innovative Food Sc And Emerging Technologies, 2009; 10: 627632.

Roy Saswati, Choudhury M. Dutta, Paul S.B. Antioxidant Potential of Rhizome of Alocasia decipiens Schott. Asian J Pharm Clin Res, 2013; 6: 120-122.

Ruch R.J., Cheng S.J., Klaunig J.E. Prevention of cytotoxicity and inhibition of intracellular communication by antioxidant catechins isolated from Chinese green tea. Carcinogen., 1989; 10:1003-1008.

Shah Rumit, Kathad Heena, Sheth Rajal \& Sheth Naveen. In vitro Antioxidant Activity of Roots of Tephrosia Purpurea Linn. International J Pharmacy Science, 2010; 2: 30-33.

Sies H. 1996. Antioxidants in Disease, Mechanisms and Therapy, Academic Press, New York.

Terao J., Piskula M.K. 1997. Flavonoids as inhibitors of lipid peroxidation in membranes. In: Flavonoids in health and disease. Marcel Dekker, New York.

Usmani Shazia. Screening for antioxidant and free radical scavenging potential of extracts of leaves and flowers of Calotropis gigantea. Asian J Pharm Clin Res, 2013; 6: 97-100.

Valentao P., Fernandes E., Carvalho F., Andrade P.B., Seabra R.M., Bastos, M. Antioxidative properties of cardoon infusion (Cynara cardunculus L.) against superoxide radical, hydroxyl radical and hypochlorous acid. Journal of Agricultural and Food Chemistry, 2002; 50: 4989-4993.

Yesilyurt V, Halfon B, \& Ozturk M, Topcu G. Antioxidant potential \& phenolic constituents of salvia cedronella. Food chemistry, 2008; 108: 31-39.

\section{How to cite this article:}

Kabita Mahato, Bibhuti Bhusan Kakoti, Sudarshana Borah, Mritunjay Kumar. In vitro antioxidative potential of methanolic aerial extracts from three ethnomedicinal plants of Assam: A Comparative Study. J App Pharm Sci, 2015; 5 (12): 111-116. 